\title{
METHODOLOGY FOR THE ASSESSMENT OF THE INDIVIDUAL RISK FOR THE HEALTH OF THE CHILDREN AGED 12-15 YEARS OLD
}

\author{
Yelizarova O.T., Hozak S.V., Stankevich T.V., Parats A.M.
} МЕТОДИКА ОЦПККИ ПНДИВДУАЛЬНОГО РИЗИКУ ДЛЯ ЗДОРОВ’Я MICЬКИХ ДIТЕЙ 12-15 POKІВ

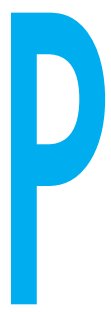

ЄЛІЗАРОВА О.Т., ГОЗАК С.В., СТАНКЕВИЧ Т.В., ПАРАЦ А.М.

ДУ «Інститут громадського здоров'я ім. О.М. Марзєєва НАМН України», м. Київ

Ключові слова: здоров'я, підлітки, індивідуальний ризик, рухова активність, індекс маси тіла, чутливість діагностичних тестів. ухова активність (РА) - один 3 провідних чинників, корекція яких $€$ передумовою профілактики неінфекційних захворювань $[1,2]$. Однак зосередження уваги на одному факторі не дає повною мірою реалізувати здоров'язбережну направленість профілактичних заходів. Тому пошук нових методів оцінки впливу комплексу зовнішніх та внутрішніх чинників на здоров'я $є$ актуальним.

Різноманітність підходів до визначення комплексного впливу факторів на здоров'я дітей та підлітків у галузі громадського здоров'я зумовлюється їхньою варіабельністю та великою кількістю сполучень. Також у медико-статистичних дослідженнях часто спостерігається мультиколінеарність факторів та обмежений інтервал розмірності їх [3]. Частковим вирішенням проблеми $€$ застосування композиційного аналізу, який дозво- ляє обґрунтувати вплив факторів режиму дня з урахуванням впливу усіх складових [4-6]. Проте, як й усі параметричні дослідження, цей підхід вимагає кількісного відображення показників, їх нормального розподілу, одного типу розмірності і не дає можливості врахувати вплив інших чинників інакше як конфаундерів. Тобто переведення системи чинників у лінійну модель $€$ водночас і недоліками методу.

Одним з підходів вирішення проблеми є створення нелінійної системи з урахуванням теорії інформації і теореми Байеса. Суть методики, що була запропонована у середині XX ст., полягала в отриманні кількісної оцінки на основі розрахунків інформаційної міри з урахуванням ступеня детермінації між класами за допомогою нескладних у реалізації ймовірнісних перетворень. Ця методика і нині успішно вико-
МЕТОДИКА ОЦЕНКИ ИНДИВИДУАЛЬНОГО РИСКА ДЛЯ ЗДОРОВЬЯ ДЕТЕЙ 12-15 ЛЕТ Елизарова Е.T., Гозак С.В., Станкевич Т.В., Парац А. H.

ГУ «Институт общественного здоровья им. А.Н. Марзеева НАМН Украины», Г. Киев

Одной из актуальных задач в сфере общественного здоровья является поиск новых методик оценки влияния комплекса внутренних и внешних факторов на здоровье с целью разработки инструментов первичной профилактики.

Цель исследования заключалась в создании модели индивидуального риска для здоровья городских подростков, занимающихся спортом/танцами в организованных коллективах, на основе изучения экзо- и эндогенных факторов с использованием теоремы Байеса. Материалы и методы. Модель разработана с учетом антропометрических, поведенческих, социальных и демографических детерминант, определенных у городских детей 12-15 лет в 2017 г. $(n=60)$ и 2018 г. $(n=54)$ на основе комплексного показателя здоровья с помощью методов теории информации. Результаты. На основе использования теоремы Байеса разработана модель оценки риска для здоровья городских подростков, занимающихся спортом. Негативно влияющими на здоровье детей факторами являются избыточная и недостаточная масса тела $(p<0,05)$, наличие хронических заболеваний $(p<0,05)$, продолжительность сна меньше 9 часов в сутки $(p<0,05)$, возраст старше 14,5 лет ( $p<0,05)$, занятия детей спортом больше и меньше 3-4 раз в неделю $(p<0,01)$ и продолжительностью меньше 270 минут в неделю для мальчиков и 230 мин в неделю для девочек $(p<0,05)$, низкий уровень доходов в семье $(p<0,05)$, отсутствие совместных занятий двигательной активностью родителей с детьми $(p<0,05)$, отсутствие занятий спортом у родителей $(p<0,05)$. На основе теоремы Байеса роздана информационная система, позволяющая оценить индивидуальный риск для здоровья подростка с учетом вышеприведенных факторов с чувствительностью $92,9 \%$ и прогностической ценностью 86, 7\%. Аналитическая точность теста - 89,3\%.

Ключевые слова: здоровье, подростки, индивидуальный риск, двигательная активность, индекс массы тела, чувствительность диагностических тестов.

( Єлізарова О.Т., Гозак С.В., Станкевич Т.В., Парац А.М. СТАТТЯ, 2019. 
METHODOLOGY FOR THE ASSESSMENT

OF THE INDIVIDUAL RISK FOR THE HEALTH

OF THE CHILDREN AGED 12-15 YEARS OLD

Yelizarova O.T., Hozak S.V., Stankevich T.V., Parats A.M.

SI «O.M. Marzieiev Institute for Public Health, NAMSU», Kyiv

A search for the new methods for the assessment of the impact of a complex of internal and external factors on health in order to develop primary prevention tools is one of the topical tasks in the sphere of public health.

Objective: We created a model of health risk for urban adolescents, engaged in sports/dance in the organized groups, based on the study of endo- and exogenous factors using Bayes theorem.

Materials and methods: The model was developed taking into account anthropometric, behavioural, social, and demographic determinants identified in urban children aged 12-15 years old in $2017(n=54)$ and 2018 ( $n=60)$ with a help of information theory methods.

Results: A model for the assessment of the health risk for urban adolescents, going in for sports, was developed on the basis of Bayes theorem. Negative factors, affecting adolescent health, are as follows: excess and insufficient body weight $(p<0.05)$, the presence of chronic diseases $(p<0.05)$, sleep less than 9 hours a day $(p<0.05)$, age over 14.5 years old $(p<0,05)$, children, going in for sports more and less 3-4 times a week $(p<0.01)$ and with a duration less than 270 minutes a week for boys and 230 minutes a week for girls $(p<0.05)$, low family income $(p<0.05)$, absence of joined motor activity of parents with children $(p<0.05)$, absence of motor activity in parents $(p<0.05)$.

Conclusions: A screening tool determines the risk of children's health deterioration taking into account the anthropometric, behavioural, social, and demographic determinants with sensitivity of $92.9 \%$, specificity of $85.7 \%$, positive predictive value of $86.7 \%$, negative predictive wave of $92.3 \%$. The test analytical accuracy is $89.3 \%$.

\section{Keywords: health, adolescents, individual risk, motor activity, body mass index, sensitivity of diagnostic tests.}

ристовується у практичній діяльності для визначення класів «здоров'я»/«хвороба» [7]. Також методологія теорії інформації використовується у складних системах розрахунків з задіянням нейронних мереж [8-10].

у сфері профілактичної медицини для визначення здоров'язбережних чинників об'єктом дослідження $€$ практично здорові діти та підлітки, стан здоров'я яких за певними ознаками поділяють на три або п'ять класів. Звісно, ці градації легко перетворюються на два класи, але при цьому втрачається частина інформації. Наприклад, під час створення інформаційної системи для визначення чинників ризику для індексу маси тіла і прогнозування ожиріння не можна враховувати лише класи дітей 3 нормальною та надмірною вагою тіла й ігнорувати клас дітей з дефіцитом маси.

Тому ми пропонуємо використовувати модифікацію методики 3 трьох/п'яти градацій стану функціонування організму на прикладі визначення ризику для здоров'я з урахуванням антропометричних, поведінкових, соціальних та демографічних детермінант.

Метою даного дослідження було створення моделі індивідуального ризику для здоров'я міських підлітків, які займаються спортом/танцями в органі- зованих колективах, на основі вивчення ендо- та екзогенних факторів з використанням теореми Байеса.

Матеріали та методи. Методику розроблено на основі даних антропометричного i фізіологічного обстежень, даних профілактичних медичних оглядів й анкетування групи міських підлітків 12-15 років $(n=54)$ та їхніх батьків. Тестування методики проведено на показниках, отриманих під час обстеження групи підлітків 12-15 років $(n=60)$, які мали фізичні навантаження помірновисокого типу кратністю 1-7 разів на тиждень 2017 року. На проведення дослідження від батьків було отримано інформовану згоду.

Для встановлення тривалості рухової активності при заняттях спортом/танцями (MVPA) використовували адаптований опитувальник «Quantification deL'Active Physiqueen Altitu de Chezle Enfants» [12]. Захворюваність вивчали шляхом викопіювання даних медичних карток.

На основі показників артеріального тиску, частоти серцевих скорочень, маси і довжини тіла, насиченості крови киснем, оцінки самопочуття та захворюваності було визначено комплексний показник здоров'я (ПЗК) [13]. Низький рівень ПЗК визначали за ПЗК $<$ $<\mathrm{M}-\sigma$, середній рівень - за $\mathrm{M}-\sigma<П 3 \mathrm{~K}_{\mathrm{i}}<\mathrm{M}+\sigma$, високий рівень - за ПЗ $\mathrm{K}_{\mathrm{i}}>\mathrm{M}+\sigma$.

У результаті дослідження ми отримали апріорні ймовірності настання події В (градації показника ПЗК) за умови супутніх подій (гіпотез) А-дії чинників (градації чинників впливу). Сума апріорних ймовірностей подій А дорівнювала 1. За теоремою Байеса ми отримали апостеріорні (умовні) ймовірності, які дозволили виділити два класи подій: наявність $\left(R_{1}\right)$ та відсутність $\left(R_{2}\right)$ ризику зниження здоров'я (формула 1):

$$
P\left(B_{j} / A\right)=\frac{P\left(B_{j}\right) \times P\left(A / B_{j}\right)}{\sum_{i=1}^{N} P\left(B_{j}\right) P\left(A / B_{j}\right)}
$$

де $P\left(B_{j} / A\right)$ - апостеріорна ймовірність настання події $B_{j}$ за гіпотезою $A ; B_{j}$ - низький, середній та високий рівні ПЗК; $A$ - градація фактора впливу.

За допомогою інформаційного підходу Кульбака С. на основі отриманих апостеріорних ймовірностей було розраховано прогностичні коефіцієнти (РС) для формування моделі прогнозування ризику зниження здоров'я підлітків (формула 2).

$P C=10 \times \frac{\log \left(P\left(R_{1} / A\right)\right.}{\left(P\left(R_{2} / A\right)\right.}$,

де $P C$ - прогностичний коефіцієнт; $\mathrm{R}_{1}$ - група 3 наявним ризиком зниження здоров'я;

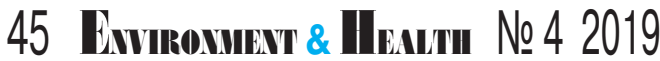


$\mathrm{R}_{2}$ - група з відсутнім ризиком зниження здоров'я; $A$ - градація фактора впливу.

Сума отриманих прогностичних коефіцієнтів утворює діагностичну функцію, медіанне значення аргументів якої брали за точку розподілу під час визначення групи ризику.

Аналітичні параметри чутливості тесту розраховували за [14].

Результати. Проведені дослідження функціонального стану, фізичного розвитку та способу життя школярів 12-15 років дозволили виявити низку факторів негативного впливу на їхнє здоров'я. Для досягнення мети комплексний показник здоров'я було розподілено на три рівні: низький, середній та високий за допомогою сигмального відхилення, а чинники - за ступенем шкідливого/корисного/нейтрального впливу на організм.

Визначено, що факторами ризику для здоров'я $€$ вік старше 14,5 років $(p<0,05)$, надмірна вага тіла або її дефіцит $(p<0,05)$, наявність хронічних захворювань $(p<0,05), \quad$ сон менше 9 годин на добу $(p<0,05)$, низький рівень фінансових можливостей сім'ї $(p<0,05)$, відсутність спільних занять руховою активністю батьків з дітьми $(p<0,05)$ та відсутність організованої фізичної активності у повсякденному житті батьків $(p<0,05)$. Також важливим фактором ризику $\epsilon$ заняття у спортивних колективах більше або менше 3-4 разів на тиждень $(p<0,01)$ та тривалістю менше 270 хв./тиждень для хлопців і 230 год./тиждень для дівчат $(p<0,05)$, а також тривалість малорухливої діяль- ності понад 4 години на добу $(\mathrm{p}<0,05)$ (табл. 1).

Ймовірність настання події В визначали за допомогою розподілу показника ПЗК на три градації. У результаті встановлено, що ймовірність формування низького рівня ПЗК $\left(\mathrm{B}_{1}\right)$ дорівнює 0,23 , середнього рівня ПЗК $\left(\mathrm{B}_{2}\right)-0,50$, високого рівня ПЗК $\left(\mathrm{B}_{3}\right)-0,27$.

Апріорні ймовірності настання події В за гіпотез А представлено у таблиці 2.

Для прикладу наведемо апріорні ймовірності для гіпотези «Тривалість сну». За тривалості сну менше 9 год./добу ймовірність формування низького рівня ПЗК становить 0,44 середнього - 0,39, високого 0,13 , а за тривалості 9 та більше год./добу відповідно 0,56, 0,61 та 0,87. Після трансформації даних згідно з теоремою Байеса (формула 1) отримуємо дві групи апостеріорної ймовірності наявності $\left(R_{1}\right)$ та відсутності $\left(\mathrm{R}_{2}\right)$ ризику для здоров'я (табл. 2). За тривалості сну менше 9 год./добу ймовір-

Розподіл учнів середнього шкільного віку за рівнями комплексного показника здоров'я та ендо- й екзогенними чинниками ризику, \%

\begin{tabular}{|c|c|c|c|c|}
\hline \multirow{2}{*}{ Фактор } & \multirow{2}{*}{ Дефініція } & \multicolumn{3}{|c|}{ Рівень ПЗК } \\
\hline & & низький & середній & високий \\
\hline \multirow{2}{*}{ Вік $(r=-0,24 ; p<0,05)$} & 11,5-14,5 років & $19,7 \pm 4,6$ & $51,3 \pm 5,7$ & $28,9 \pm 5,2$ \\
\hline & 14,5-15,5 років & $47,6 \pm 10,9$ & $38,1 \pm 10,6$ & $14,3 \pm 7,6$ \\
\hline \multirow{2}{*}{$\operatorname{IMT}(r=0,25 ; p<0,05)$} & надмірна/дефіцит & $38,9 \pm 11,5$ & $50,0 \pm 11,8$ & $11,1 \pm 7,4$ \\
\hline & нормальна & $16,0 \pm 4,2$ & $52,0 \pm 5,8$ & $32,0 \pm 5,4$ \\
\hline \multirow{2}{*}{ Хронічні захворювання $(r=0,21 ; p<0,05)$} & наявні & $28,0 \pm 9,0$ & $64,0 \pm 9,6$ & $8,0 \pm 5,4$ \\
\hline & відсутні & $20,9 \pm 5,0$ & $46,3 \pm 6,1$ & $32,8 \pm 5,7$ \\
\hline \multirow{2}{*}{ Тривалість сну $(r=0,22 ; p<0,05)$} & менше 8,9 год./добу & $31,8 \pm 9,9$ & $59,1 \pm 10,5$ & $9,1 \pm 6,1$ \\
\hline & більше 9 год./добу & $18,0 \pm 4,9$ & $52,5 \pm 6,4$ & $29,5 \pm 5,8$ \\
\hline \multirow{3}{*}{ Кратність занять $(r=-0,36 ; p<0,01)$} & 3-4 рази & $13,0 \pm 5,0$ & $54,3 \pm 7,3$ & $32,6 \pm 6,9$ \\
\hline & 1-2 рази & $55,6 \pm 16,6$ & $22,2 \pm 13,9$ & $22,2 \pm 13,9$ \\
\hline & 5-7 разів & $33,3 \pm 27,2$ & $33,3 \pm 27,2$ & $33,3 \pm 27,2$ \\
\hline \multirow{2}{*}{ Тривалість MVPA ( $\left.\chi^{2}=6,1 ; p<0,05\right)$} & менше 270/230 год./тиж. & $30,8 \pm 9,1$ & $50,0 \pm 9,8$ & $19,27,7$ \\
\hline & більше 270/230 год./тиж. & $6,3 \pm 4,3$ & $65,6 \pm 8,4$ & $28,17,9$ \\
\hline \multirow{2}{*}{$\begin{array}{l}\text { Тривалість малорухливої діяльності у } \\
\text { позашкільний час }(r=-0,26 ; p<0,05)\end{array}$} & менше 4 год./добу & $16,7 \pm 6,8$ & $40,0 \pm 8,9$ & $43,3 \pm 9,0$ \\
\hline & більше 4 год./добу & $29,7 \pm 5,7$ & $53,1 \pm 6,2$ & $17,2 \pm 4,7$ \\
\hline \multirow{2}{*}{$\begin{array}{l}\text { Заняття батьків організованою РА } \\
(r=-0,26 ; p<0,05)\end{array}$} & Tak & $13,8 \pm 6,4$ & $37,9 \pm 9,0$ & $48,3 \pm 9,3$ \\
\hline & $\mathrm{Hi}$ & $25,4 \pm 5,3$ & $53,7 \pm 6,1$ & $20,9 \pm 5,0$ \\
\hline \multirow{2}{*}{$\begin{array}{l}\text { Заняття батьків РА разом з дитиною } \\
(r=-0,26 ; p<0,05)\end{array}$} & Так & $7,1 \pm 4,9$ & $64,3 \pm 9,1$ & $28,6 \pm 8,5$ \\
\hline & $\mathrm{Hi}$ & $30,3 \pm 5,7$ & $45,5 \pm 6,1$ & $24,2 \pm 5,3$ \\
\hline \multirow{2}{*}{ Рівень доходів сім'ї $(r=0,26 ; p<0,05)$} & низький & $30,6 \pm 7,7$ & $52,8 \pm 8,3$ & $16,7 \pm 6,2$ \\
\hline & середній & $11,5 \pm 4,4$ & $55,8 \pm 6,9$ & $32,7 \pm 6,5$ \\
\hline
\end{tabular}


ність наявності ризику для здоров'я становить 0,30, ймовірність відсутності ризику - 0,11. За тривалості сну 9 та більше год./добу ймовірності становлять $\mathrm{R}_{1}=0,19$ і $\mathrm{R}_{2}=0,36$.

Далі за формулою 2 визначаємо прогностичні коефіцієнти, які наведено у таблиці 3. При цьому $\mathrm{PC}_{0}$ - це міра інформативності без логарифмування, РС - прологарифмовані показники, а $\mathrm{PC}_{1}$ - коефіцієнти, що використовуються для визначення ризику під час проведення досліджень. Величина коефіцієнтів $\mathrm{PC}_{0}$ свідчить про ступінь відмінності ймовірностей між групами $\mathrm{R}_{1}$ та $\mathrm{R}_{2}$ ризику зниження здоров'я. Чим більше значення коефіцієнта відрізняється від одиниці, тим більш значимим є вплив даного фактора. Діапазон отриманих діагностичних коефіцієнтів РС становив від -6 до +6, тому для зручності сприйняття їх переводили у показник PC1 зі шкалою від 0 до 12.

Ранжування факторів за значущістю щодо наявності ризику зниження здоров'я має такий рейтинг:

1 - надмірна маса тіла або їі дефіцит $(3,91)$;

2 - наявність хронічних захворювань $(3,28)$;

3 - кратність занять спортом/танцями 1-2 рази на тиждень $(3,07)$;

4 - тривалість сну менше 9 год./добу $(2,78)$;

5 - вік підлітка старше 14,5 років $(2,72)$;

6 - низький рівень доходів ciм'ï $(2,03)$;

7 - тривалість занять спортом/танцями $(1,83)$;

8 - малорухлива діяльність у позашкільний час понад 4 год./добу $(1,41)$;

9 - відсутність занять батьків організованою РА $(1,32)$;

10 - відсутність занять батьків фізичними вправами разом з дитиною $(1,11)$.

За значущістю щодо відсутності ризику зниження здоров'я фактори розташувалися так:

1 - тривалість занять спортом/танцями більше 270 хв. на тиждень для хлопців та більше Таблиця 2

\section{Апріорні та апостеріорні ймовірності розподілу міських підлітків за рівнями} комплексного показника здоров'я

\begin{tabular}{|c|c|c|c|c|c|c|}
\hline Показник & Градації (A) & Низький ПЗК & Середній ПЗК & Високий ПЗК & $\mathrm{R}_{1}$ & $\mathrm{R}_{2}$ \\
\hline \multirow{3}{*}{$\begin{array}{l}\text { Наявність хро- } \\
\text { нічних захво- } \\
\text { рювань }\end{array}$} & наявні & 0,33 & 0,34 & 0,08 & 0,28 & 0,09 \\
\hline & відсутні & 0,67 & 0,66 & 0,92 & 0,21 & 0,35 \\
\hline & $\mathrm{B}_{\mathrm{j}}$ & 0,23 & 0,50 & 0,27 & & \\
\hline \multirow{3}{*}{ Вік } & $14,5-15,5$ років & 0,40 & 0,17 & 0,12 & 0,44 & 0,16 \\
\hline & $11,5-14,4$ років & 0,60 & 0,83 & 0,88 & 0,17 & 0,31 \\
\hline & $B_{j}$ & 0,23 & 0,50 & 0,27 & & \\
\hline \multirow{3}{*}{ IMT } & Надмірна МТ/дефіцит МТ & 0,37 & 0,19 & 0,08 & 0,42 & 0,11 \\
\hline & Нормальна МТ & 0,63 & 0,81 & 0,92 & 0,18 & 0,32 \\
\hline & $\mathrm{B}_{\mathrm{j}}$ & 0,23 & 0,50 & 0,27 & & \\
\hline \multirow{3}{*}{$\begin{array}{l}\text { Тривалість } \\
\text { сну }\end{array}$} & менше 9 год./добу & 0,44 & 0,39 & 0,13 & 0,30 & 0,11 \\
\hline & 9 та більше год./добу & 0,56 & 0,61 & 0,87 & 0,19 & 0,36 \\
\hline & $\mathrm{B}_{\mathrm{j}}$ & 0,23 & 0,50 & 0,27 & & \\
\hline \multirow{4}{*}{$\begin{array}{l}\text { Кратність } \\
\text { занять }\end{array}$} & 1-2 рази/тиж. & 0,50 & 0,07 & 0,11 & 0,59 & 0,19 \\
\hline & 3-4 рази/тиж. & 0,50 & 0,89 & 0,83 & 0,14 & 0,29 \\
\hline & 5-7 разів/тиж. & 0,08 & 0,04 & 0,06 & 0,36 & 0,30 \\
\hline & $\mathrm{B}_{\mathrm{j}}$ & 0,23 & 0,50 & 0,27 & & \\
\hline \multirow{3}{*}{$\begin{array}{l}\text { Тривалість } \\
\text { МVPA } \\
\text { на тиждень }\end{array}$} & менше 270/230 год./тиж. & 0,80 & 0,38 & 0,36 & 0,39 & 0,21 \\
\hline & більше 270/230 год./тиж. & 0,20 & 0,62 & 0,64 & 0,09 & 0,34 \\
\hline & $\mathrm{B}_{\mathrm{j}}$ & 0,23 & 0,50 & 0,27 & & \\
\hline \multirow{3}{*}{$\begin{array}{l}\text { Заняття } \\
\text { батьків органі- } \\
\text { зованою РА }\end{array}$} & $\mathrm{Hi}$ & 0,81 & 0,77 & 0,50 & 0,26 & 0,20 \\
\hline & так & 0,19 & 0,23 & 0,50 & 0,15 & 0,47 \\
\hline & $B_{j}$ & 0,23 & 0,50 & 0,27 & & \\
\hline \multirow{3}{*}{$\begin{array}{l}\text { Заняття РА } \\
\text { разом } \\
3 \text { дитиною }\end{array}$} & $\mathrm{Hi}$ & 0,91 & 0,63 & 0,67 & 0,29 & 0,26 \\
\hline & так & 0,09 & 0,38 & 0,33 & 0,07 & 0,31 \\
\hline & $B_{j}$ & 0,23 & 0,50 & 0,27 & & \\
\hline \multirow{3}{*}{$\begin{array}{l}\text { Рівень } \\
\text { доходів } \\
\text { сім'ї }\end{array}$} & низький & 0,65 & 0,40 & 0,26 & 0,35 & 0,17 \\
\hline & середній & 0,35 & 0,60 & 0,74 & 0,14 & 0,35 \\
\hline & $\mathrm{B}_{\mathrm{j}}$ & 0,23 & 0,50 & 0,27 & & \\
\hline \multirow{3}{*}{$\begin{array}{l}\text { Малорухлива } \\
\text { активність }\end{array}$} & більше 4 год. & 0,79 & 0,74 & 0,46 & 0,27 & 0,19 \\
\hline & менше 4 год. & 0,21 & 0,26 & 0,54 & 0,14 & 0,46 \\
\hline & $B_{j}$ & 0,23 & 0,50 & 0,27 & & \\
\hline
\end{tabular}


Таблиця 3230 хв. на тиждень для дівчат

Прогностичні коефіцієнти для визначення ймовірності наявності ризику для здоров'я підлітків

\begin{tabular}{|c|c|c|c|c|}
\hline Показник & Градація & $\mathrm{PC}_{0}$ & PC & $\mathrm{PC}_{1}$ \\
\hline \multirow{2}{*}{ Вік } & 14,5-15,5 років & 2,72 & 4 & 10 \\
\hline & $11,5-14,4$ років & 0,56 & -3 & 3 \\
\hline \multirow{2}{*}{$\begin{array}{l}\text { Наявність хронічних } \\
\text { захворювань }\end{array}$} & наявні & 3,28 & 5 & 11 \\
\hline & відсутні & 0,59 & -2 & 4 \\
\hline \multirow{2}{*}{ IMT } & надмірна/дефіцит & 3,91 & 6 & 12 \\
\hline & нормальна & 0,56 & -3 & 3 \\
\hline \multirow{2}{*}{ Тривалість сну } & менше 8,9 год./добу & 2,78 & 4 & 10 \\
\hline & більше 9 год./добу & 0,52 & -3 & 3 \\
\hline \multirow{3}{*}{ Кратність занять } & 1-2 рази/тиж. & 3,07 & 5 & 11 \\
\hline & 3-4 рази/тиж. & 0,49 & -3 & 3 \\
\hline & 5-7 разів/тиж. & 1,21 & 1 & 7 \\
\hline \multirow{2}{*}{ Тривалість MVPA } & менше 270/230 год./тиж. & 1,83 & 3 & 9 \\
\hline & більше 270/230 год./тиж. & 0,25 & -6 & 0 \\
\hline \multirow{2}{*}{$\begin{array}{l}\text { Заняття батьків } \\
\text { організованою РА }\end{array}$} & $\mathrm{Hi}$ & 1,32 & 1 & 7 \\
\hline & так & 0,31 & -5 & 1 \\
\hline \multirow{2}{*}{$\begin{array}{l}\text { Заняття РА разом } \\
\text { з дитиною }\end{array}$} & $\mathrm{Hi}$ & 1,11 & 0 & 6 \\
\hline & так & 0,22 & -6 & 0 \\
\hline \multirow{2}{*}{ Рівень доходів сім'ї } & низький & 2,03 & 3 & 9 \\
\hline & середній & 0,39 & -4 & 2 \\
\hline \multirow{2}{*}{$\begin{array}{l}\text { Малорухлива діяльність } \\
\text { у позашкільний час }\end{array}$} & більше 4 год. & 1,41 & 1 & 7 \\
\hline & менше 4 год. & 0,31 & -5 & 1 \\
\hline
\end{tabular}

Розподіл прогностичних коефіцієнтів діагностичної функції за ступенем ризику для здоров'я

Показник Колмогорова-Смирнова $d=0,06, p>0,20$ Lilliefors $p<0,15$

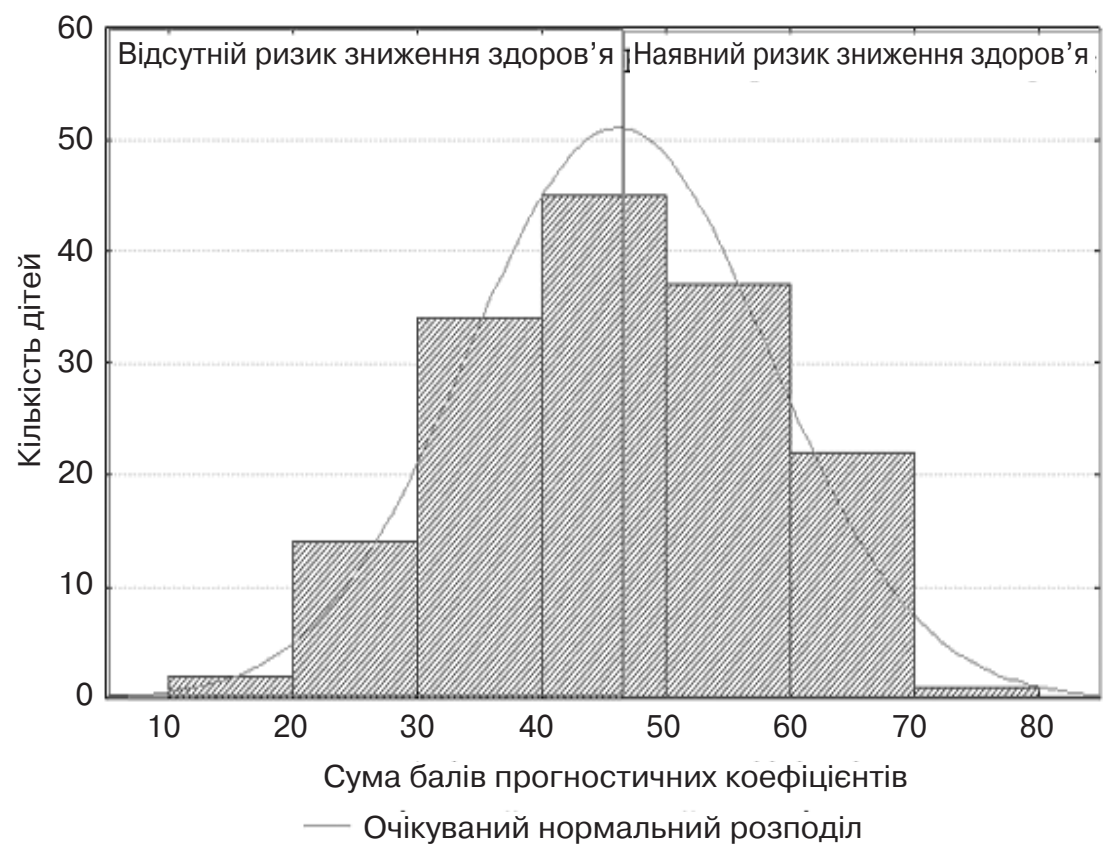

$(0,25)$;

2 - заняття батьків організованою РА $(0,31)$ та тривалість малорухливої активності підлітка менше 4-х годин на добу $(0,31)$;

3 - середній рівень доходу сім'ї $(0,39)$;

4 - кратність занять спортом/танцями 3-4 рази на тиждень $(0,49)$;

5 - тривалість сну 9 та більше год./добу $(0,52)$;

6 - вік $11,5-14,4$ років $(0,56)$ та нормальна маса тіла $(0,56)$;

7 - відсутність хронічних захворювань $(0,59)$.

Проведена оцінка ризику для здоров'я у групі міських підлітків за визначеними прогностичними коефіцієнтами дозволила отримати прогностичну функцію зі значенням аргументу у діапазоні від 17 до 87 балів 3 медіанним значенням 47,0 (ймовірність 0,5) (рис.). Отже, для значення аргументу менше 47,0 можна вважати, що ризик для здоров'я відсутній, а для значення аргументу понад 47,1 ризик для здоров'я наявний

За допомогою тестування отриманих критеріїв ризику на результатах 2017-2018 років ми визначили, наскільки коректно діагностична модель розподіляє учасників експерименту на групи з низьким або високим рівнями здоров'я. Порівнявши розраховані оцінки з реальним рівнем ПЗК, ми виявили, що вірно визначено наявність ризику у 13 підлітків з низьким рівнем ПЗК (істинно позитивний результат), а хибний результат виявлено у двох підлітків. Відсутність ризику для здоров'я (істинно негативний результат) правильно визначено у 12 осіб, а хибно - в одного. На основі отриманих даних були розраховані параметри чутливості тесту з застосуванням підходів доказової медицини (табл. 4).

Встановлено, що чутливість тесту дорівнює 92,9\%, специфічність тесту - 85,7\%, прогноз позитивного результату $86,7 \%$, прогноз негативного результату - 92,3\%. Аналітична точність тесту становить 89,3\%.

Наведемо приклади оцінки індивідуального ризику погіршання здоров'я для двох учнів 5-го класу (табл. 5).

Приклад 1. Хлопець 12 років 3 хронічними захворюваннями IMT=15,8 кг/M², що відповідає 
нормальному фізичному розвитку за таблицями ВООЗ. Поведінкові фактори: тривалість сну - 9 год./добу, тривалість малорухливої діяльності у позашкільний час - у середньому 180 хв./добу, кратність занять у спортивному гуртку 2 на тиждень по 90 хвилин. Батьки не відвідують спортивні заклади, не займаються спортивними заняттями самостійно, не займаються руховою активністю разом 3 дитиною. Рівень доходів сім'ї - середній. Сума прогностичних коефіцієнтів (табл. 3, графа $\mathrm{PC}_{1}$ ) дорівнює 56, що вище точки розподілу $(47,0)$, отже ризик для здоров'я наявний. Комплексний показник здоров'я також відповідає низькому рівню. Батькам рекоменду- ється звернути увагу на режим тренувань дитини та спільні рекреаційні заняття, а також щорічно проводити профілактичні медичні огляди дитини.

Приклад 2. Дівчина 12 років, IMT=14,4 кг/M², що за таблицями ВООЗ відповідає дефіциту маси тіла. Хронічні захворювання відсутні. Поведінкові фактори: тривалість сну - 9 год./добу, тривалість малорухливої діяльності у позашкільний час - у середньому 360 хв./добу, кратність занять у спортивному гуртку - 3 на тиждень по 90 хвилин. Батьки не відвідують спортивні заклади, не займаються спортивними заняттями самостійно, не займаються руховою активністю разом з дитиною. Рівень доходів у сім'ї - низький. Сума про- гностичних коефіцієнтів (табл. 3 , графа $\mathrm{PC}_{1}$ ) дорівнює 54, що вище точки розподілу $(47,0)$. Отже, ризик для здоров'я наявний. Комплексний показник здоров'я відповідає середньому рівню. Батькам рекомендується переглянути режим дня дитини та організацію харчування, спільно з дитиною займатися РA на дозвіллі, щорічно проводити профілактичні медичні огляди дитини.

\section{ВисновКИ}

1. Встановлено, що чинниками ризику зниження здоров'я підлітків є надмірна маса тіла або її дефіцит $(p<0,05)$, наявність хронічних захворювань $(p<0,05)$, сон менше 9 год. на добу $(p<0,05)$, вік старше 14,5 років $(p<0,05)$, низький рівень доходів сім'ї $(p<0,05)$, відсут-

Параметри чутливості тесту

Таблиця 4

\begin{tabular}{|c|c|c|c|c|}
\hline \multirow{2}{*}{$\begin{array}{c}\text { Ризик зниження } \\
\text { здоров'я }\end{array}$} & \multicolumn{2}{|c|}{ Рівень ПЗК } & \multicolumn{2}{|c|}{ Рівень ПЗК } \\
\hline & Низький & Високий & Низький & Високий \\
\hline Наявний & Істинно позитивний (a) & Хибно позитивний (b) & 13 & 2 \\
\hline Відсутній & Хибно негативний (с) & Істинно негативний (d) & 1 & 12 \\
\hline \multicolumn{5}{|c|}{$\begin{array}{l}\text { Чутливість тесту }(\mathrm{Se})=\mathrm{a} /(\mathrm{a}+\mathrm{c})=92,9 \% ; \\
\text { специфічність }(\mathrm{Sp})=\mathrm{d} /(\mathrm{b}+\mathrm{d})=85,7 \% ; \\
\text { прогноз позитивого результату }(+\mathrm{PV})=\mathrm{a} /(\mathrm{a}+\mathrm{b})=86,7 \% \text {; } \\
\text { прогноз негативного результату }(-\mathrm{PV})=\mathrm{d} /(\mathrm{c}+\mathrm{d})=92,3 \% . \\
\text { аналітична точність тесту }=(\mathrm{a}+\mathrm{d}) /(\mathrm{a}+\mathrm{b}+\mathrm{c}+\mathrm{d})=89,3 \% .\end{array}$} \\
\hline
\end{tabular}

Приклади застосування розробленої моделі для оцінки індивідуального ризику учнів середнього шкільного віку

\begin{tabular}{|c|c|c|c|c|}
\hline \multirow{2}{*}{ Показник } & \multicolumn{2}{|l|}{ Учень 1} & \multicolumn{2}{|l|}{ Учень 2} \\
\hline & Значення показника & $\mathrm{PC}_{1}$ & Значення показника & $\mathrm{PC}_{1}$ \\
\hline Стать & хлопець & - & дівчина & - \\
\hline Вік & 12 років & 3 & 12 & 3 \\
\hline Хронічні захворювання & наявні & 11 & відсутні & 4 \\
\hline IMT & 15,8 кг/м² (нормальна вага) & 3 & 14,4 кг/м² (дефіцит ваги) & 12 \\
\hline Тривалість сну & 9 годин на добу & 3 & 9 годин на добу & 3 \\
\hline Кратність занять спортом & 2 рази на тиждень & 11 & 3 рази на тиждень & 3 \\
\hline Тижнева тривалість занять спортом & 180 хв. на тиждень & 9 & 270 хв. на тиждень & 0 \\
\hline Малорухлива діяльність у позашкільний час & 180 хв. на добу & 1 & 360 хв. на добу & 7 \\
\hline Заняття батьків організованою РА & $\mathrm{Hi}$ & 7 & $\mathrm{Hi}$ & 7 \\
\hline Спільні заняття РА батьків з дитиною & $\mathrm{Hi}$ & 6 & $\mathrm{Hi}$ & 6 \\
\hline Рівень доходів сім'ї & середній & 2 & низький & 9 \\
\hline$\sum_{\mathrm{t}=1}^{1_{0}} \mathrm{PC}_{1 i}$ & \multicolumn{2}{|l|}{56} & \multicolumn{2}{|l|}{54} \\
\hline Висновок & \multicolumn{2}{|c|}{$\begin{array}{c}\text { Наявність ризику зниження } \\
\text { здоров'я }\end{array}$} & \multicolumn{2}{|c|}{$\begin{array}{c}\text { Наявність ризику зниження } \\
\text { здоров'я }\end{array}$} \\
\hline ПЗК & \multicolumn{2}{|c|}{$\begin{array}{c}\text { Значення ПЗК }=50,1 \text {, що } \\
\text { відповідає низькому рівню }\end{array}$} & \multicolumn{2}{|c|}{$\begin{array}{c}\text { Значення ПЗК = 59,4, що } \\
\text { відповідає середньому рівню }\end{array}$} \\
\hline
\end{tabular}


ність спільної РА батьків з дітьми $(p<0,05)$, відсутність організованої фізичної активності у повсякденному житті батьків $(p<0,05)$. Також важливим фактором ризику $є$ заняття спортом/танцями більше або менше 3-4 разів на тиждень $(p<0,01)$ та тривалістю менше 270 хв./тиждень для хлопців і 230 год./тиждень для дівчат $(p<0,05)$.

2. На основі використання теореми Байеса створено інформаційну систему, яка дозволяє визначити наявність ризику зниження здоров'я підлітка з урахуванням вищезазначених чинників з чутливістю 92,9\% та прогностичною цінністю 86,7\%. Аналітична точність тесту становить 89,3\%. У процесі розробки моделі було визначено, що найбільш значущими чинниками ризику зниження здоров'я $€$ надмірна маса тіла або її дефіцит $(3,91)$; наявність хронічних захворювань $(3,28)$; кратність занять спортом/танцями 1-2 рази на тиждень $(3,07)$. За значущістю щодо відсутності ризику зниження здоров'я підлітків найбільш значимими є тривалість занять спортом/танцями понад 270 хв. на тиждень для хлопців та більше 230 хв на тиждень для дівчат $(0,25)$; заняття батьків організованою PA $(0,31)$ та тривалість малорухливої активності підлітка у позашкільний час менше 4-х годин на добу $(0,31)$; середній рівень доходу сім'ї $(0,39)$; кратність занять спортом/танцями 3-4 рази на тиждень $(0,49)$.

ЛІТЕРАТУРА

1. WHO. Physical activity strategy for the WHO European Region 2016-2025. 2016. 32 p.

2. Booth F.W., Roberts C.K., Laye M.J. Lack of exercise is a major cause of chronic diseases. Compr. Physiol. 2012. Vol. 2 (2). P. 1143-211. doi: 10.1002/cphy.c110025

3. Антомонов М.Ю. Математическая обработка и анализ медико-биологических данных. К. : Мединформ, 2018. 579 c.

4. Strugnell C., Turner K., Malakellis M., Hayward J., Foster C., Millar L., Allender S. Composition of objectively measured physical activity and sedentary behaviour participation across the school-day, influence of gender and weight status: cross-sectional analyses among disadvantaged Victorian school children. BMJ Open. 2016. Vol. 6 (9). e011478. http://dx.doi.org/10.1136/bmjo pen-2016-011478

5. Gupta N., Mathiassen S.E., Mateu-Figueras G., Heiden M., Hallman D.M., Jwrgensen M.B. Holtermann A. A comparison of standard and compositional data analysis in studies addressing group differences in sedentary behavior and physical activity. Int J Behav Nutr Phys Act. 2018 Vol. 15 (1). P. 53-67. doi:

10.1186/s12966-018-0685-1.

6. Foley L., Dumuid D.,

Atkin A.J., Olds T., Ogilvie D.

Patterns of health behaviour associated with active travel: a compositional data analysis. Int J Behav Nutr Phys Act. 2018. Vol. 15 (1). P. 26-38.

7. Пересипкіна Т.В.,

Редька І.В., Сидоренко Т.П., Пересипкіна А.M.

Інформаційна значущість медико-соціальних факторів, які впливають на здоров'я орієнтовану поведінку школярів. Здоровье ребенка. 2019. Vol. 14. № 3. P. 165-170.

8. Petzschner F.H., Weber L.A.E., Gard T., Stephan K.E. Computational Psychosomatics and Computational Psychiatry:

Toward a Joint Framework for Differential Diagnosis. Bio. I

Psychiatry. 2017. Vol. 82 (6). P. 421-430.

9. Pillai P.S., Leong T.Y.

Alzheimer's Disease

Neuroimaging Initiative.

Modeling Multi-View

Dependence in Bayesian

Networks for Alzheimer's

Disease Detection. Stud Health

Technol Inform. 2019. Vol. 21.

P. 358-362

10. Labelle C., Marinier A., Lemieux S. Enhancing the drug discovery process: Bayesian inference for the analysis and comparison of dose-response experiments. Bioinformatics. 2019. Vol. 35 (14)

P. i464-i473.

11. Barbosa N., Sanchez C.E., Vera J.A. et al. A physical activity questionnaire: Reproducibility and validity. Journal of Sports Science and Medicine. 2007. Vol. 6. P. 505-518.

12. Полька Н.С., Гозак С.В. Єлізарова О.Т., Станкевич Т.В., Парац А.М. Новітній підхід до оцінювання здоров'я підлітків у гігієнічних дослідженнях Журнал НАМН України. 2019. T. 25. № 3. C. 227-231.
13. Москаленко В.Ф. Булах І.Є., Пузанова О.Г. Методологія доказової медицини. Київ : Медицина, 2014. $200 \mathrm{c}$.

\section{REFERENCES}

1. WHO. Physical Activity Strategy for the WHO European Region 2016-2025. 2016 : 32 p.

2. Booth F.W., Roberts C.K. and Laye M.J. Compr. Physiol. 2012 ; 2 (2) : 1143-211. doi: 10.1002/cphy.c110025

3. Antomonov M.Yu.

Matematicheskaya obrabotka I analiz medico-biologicheskikh dannykh [Mathematical Processing and Analysis of Medico-Biological Data]. Kyiv : Medinform ; 2018 : 579 p. (in Russian).

4. Strugnell C., Turner K., Malakellis M., Hayward J., Foster C., Millar L. and Allender S. BMJ Open. 2016 ; 6 (9). e011478.

http://dx.doi.org/10.1136/bmjo pen-2016-011478

5. Gupta N., Mathiassen S.E., Mateu-Figueras G., Heiden M., Hallman D.M., Jwrgensen M.B. and Holtermann A. Int J Behav Nutr Phys Act. 2018 ; 15 (1) : 53-67. doi: 10.1186/s12966018-0685-1.

6. Foley L., Dumuid D., Atkin A.J., Olds T. and Ogilvie D. Int J Behav Nutr Phys Act. 2018 ; 15 (1) : 26-38.

7. Peresypkina T.V., Redka I.V., Sydorenko T.P. and Peresypkina A.M. Zdorovie Rebenka (Child's Health). 2019. Vol. 14. №. 3. P. 165-170 (in Ukrainian). 8. Petzschner F.H.,

Weber L.A.E., Gard T. and Stephan K.E. Biol Psychiatry. 2017 ; 82 (6) : 421-430.

9. Pillai P.S. and Leong T.Y. Stud Health Technol Inform. 2019 ; 21 : 358-362.

10. Labelle C., Marinier A. and Lemieux S. Bioinformatics. 2019 : 35(14) : i464-i473.

11. Barbosa N., Sanchez C.E., Vera J.A. et al. Journal of Sports Science and Medicine. 2007 ; $6: 505-518$.

12. Polka N.S., Hozak S.V. Yelizarova O.T., Stankevych T.V. and Parats A.M. Zhurnal NAMN Ukrainy. 2019 ; 25 (3) : 227-231 (in Ukrainian).

13. MoskalenkoV.F.,

Bulakh I.Ye. and Puzanova O.H. Metodolohiia dokazovoi medytsyny [Methodology of Probative Medicine]. Kyiv : Medytsyna 2014 : 200 p. (in Ukrainian).

Надійшла до редакції 27.08.2019 